\title{
Toward the development of a weather index insurance for rice farmers in the coastal region of Myanmar
}

\author{
Jun Furuya ${ }^{1} \cdot$ Keisuke Omori $^{2} \cdot$ Hideo Aizaki $^{3}$ \\ Accepted: 12 June 2021 / Published online: 22 June 2021 \\ (c) The Author(s) 2021
}

\begin{abstract}
Climate change is expected to exacerbate damage to agricultural production from natural disasters. Examination of measures to adapt to the damage represents an urgent matter for agriculture. A multidisciplinary research project aimed at providing effective information related to development a weather index insurance (WII) system was conducted for rice farmers in a coastal region of Myanmar to achieve sustainable rice farm management in the country, which is among the world's poorest and most disaster prone. For lower income countries, WII is one adaptation measure to mitigate damage by climate change. Using remote sensing and statistical data, changes in tracks of cyclones in the Bay of Bengal, the duration of damage by cyclone disasters, and areas affected by saltwater intrusion were analyzed to ascertain risk levels for disasters in the target area: Labutta township in the Ayeyarwady region. Furthermore, demand analysis of WII using discrete choice experiments, a question-based statistical survey method, revealed that farmers' demand of WIIs for cyclone landfall, flood, and drought is relatively greater than that for saltwater intrusion. This finding indicates that saltwater intrusion might not be a crucially important matter for farmers who cultivate rainfed rice, whereas inland water floods caused by cyclone landfall and drought caused for changing the weather patterns represent a threat for these farmers. Results of econometric model analysis for designing a WII indicate that if a regular farmer in the township were to pay 41.5 US dollars per year to purchase WII for flood damage, their expected income will be stable.
\end{abstract}

Keywords Coastal region $\cdot$ Economic analysis $\cdot$ Myanmar $\cdot$ Satellite data analysis $\cdot$ Weather index insurance (WII)

\section{Introduction}

It is still fresh in our memory that heavy rains in the west coast of India in 2018 (Viswanadhapalli et al. 2019) and in the downstream basin of the Yangtze River in 2020 took the lives of many people (Wei et al. 2020). Mitigation of such damage, probably caused by climate change, is an urgent matter. Insurance can be regarded as an adaptive measure to ameliorate damage by climate change. In

Jun Furuya

furuya@affrc.go.jp

1 Social Sciences Division, Japan International Research Center for Agricultural Sciences, 1-1 Ohwashi, Tsukuba, Ibaraki 305-8686, Japan

2 Research Planning and Partnership Division, Japan International Research Center for Agricultural Sciences, 1-1 Ohwashi, Tsukuba, Ibaraki 305-8686, Japan

3 Research Faculty of Agriculture, Hokkaido University, Kita 9, Nishi 9, Kita-ku, Sapporo, Hokkaido 060-8589, Japan fact, total insurance payments of the three major Japanese non-life insurance companies in 2018 reached their highest amount ever because of continuous erratic rains and landing of typhoons covering wide areas (General Insurance Association of Japan 2019). These frequent extreme events have increased latent demands for insurance not only for life but also for equipment and products.

Since the cyclone Nargis catastrophe, which took the lives of more than 100 thousand peoples in Myanmar in 2008, measures to adapt to such extreme events have been sought by farmers in coastal regions. Crop insurance is an important candidate among measures for adaptation to climate change. It stabilizes farm management by paying compensation when the farm is damaged by a disaster.

However, farmers who buy crop insurance would sometimes abandon their agricultural production under severe climate conditions. Furthermore, grasping the effects of crop damage entails some costs to insurance companies in the target countries. These problems of adverse selection and high transaction costs pose obstacles hindering the 
dissemination of crop insurance to economically developing countries (Barnett and Mahul 2007).

To address these difficulties of traditional crop insurance, index insurance has been proposed for sustainable farm management in lower income countries (Collier et al. 2009). Index insurance is insurance for which payments are determined by weather indices such as rainfall or temperature. The insurance has no adverse selection because the farmers' activities will not respond to insurance payments. Furthermore, the cost of assessing hazard effects is quite low because the payment is based solely on the weather index.

However, a shortcoming of this index insurance has been reported by Elabed et al. (2013). It is called basis risk, which derives from differences in rainfall or temperature between farms and a meteorological observation station. If the farm faces damage from extraordinary weather, and if the meteorological observation station does not record the short rainfall or high temperature, then the farmer will not be able to receive an insurance payment. Farmers who buy index insurance will be forced to participate in a kind of compound lottery based on weather risk and the basis risk (Elabed and Carter, 2015). Risk-averse farmers will avoid buying the weather index insurance. Therefore, examining a way of decreasing the basis risk is an important task to develop a valid WII system.

To decrease the basis risk, new indices such as the salt level of water and soil were investigated using satellite data and station reports. Not only data collection but also the demand and design of index insurance were examined for this project.

\section{Project outline}

The WII is a measure for adaptation to climate change. Some countries such as Thailand and India have already introduced this measure to promote stable agricultural production (Chantarat et al. 2012). As described, the monitoring and transaction costs of this type of insurance are lower than those of conventional crop insurance. Therefore, it is suitable for many developing countries. As measures for agricultural production adaptation to climate change, this project was designed by the Japan International Research Center for Agricultural Sciences (JIRCAS).

\section{Project period and target area}

The project period was five years, starting in 2016. Before the start, some trials of the target area were investigated. The Khulna district of Bangladesh was chosen as the first target area because this region was also affected by cyclone landfalls. Farm surveys had been conducted for a climate change project. However, the plan was canceled because of deteriorating security in this country. The second candidate area was in the West Bengal state of India contiguous to the Khulna region. However, WII had already been introduced by the government: Many farmers whose land had been damaged by two powerful cyclones, i.e., "Aila" and "Sidr," changed their activities to shrimp farming from rice cropping (Raju et al. 2016).

In light of those circumstances, the target area was fixed as the Ayeyarwady region in Myanmar as a region that is strongly and adversely affected by cyclone disasters. Moreover, the low population density of this country is one key factor affecting the target area. In a country with high population density such as Bangladesh, conventional crop insurance is suitable because the labor cost for crop damage investigation is extremely low. The WII does not entail damage inspection costs. Therefore, insurance of this type is acceptable for Myanmar. ${ }^{1}$

During the first year of this project, the preliminary farm survey was administrated in the Ayeyarwady region. Considering the degree of damage meted out by the cyclone disaster in 2008, Labutta township was selected as a project target area. Figure 1 exhibits Labutta township in the Ayeyarwady region. A list of farmers from ten village tracts in this township was compiled for random data sampling. A small river flowing to the Yway River was selected for investigation of water saline levels. Between the second and fourth years of the project, farm surveys to collect data related to rice production and responses to the discrete choice experiments questions related to WII demand were conducted. Furthermore, ground truth and data collection of water saline level for satellite image analyses were carried out. In the fourth and the final year of this project, the gathered data were analyzed for each topic.

\section{Causality of weather shock to production}

The target area is in a cyclone and flood disaster-prone region in the country. Figure 2 portrays the causality of weather shocks to agricultural production in this area. First, if a large cyclone strikes in this coastal area and if high tides occur, the river water level will rise immediately. However, this cyclone landfall can be expected to destroy embankments of this area. These two effects can be expected, in turn, to cause saline water intrusion in the paddy fields and to decrease rice yields. Secondly, the

\footnotetext{
${ }^{1}$ Despite the existence of basis risk, Sompo Japan Nipponkoa and a consortium temporarily started selling weather index insurance (WII) for drought to sesame farmers in Myanmar in 2019 because the benefit of low monitoring costs, low transaction costs, and no adverse selection was able to overcome the various associated shortcomings (SOMPO 2019).
} 
Fig. 1 Labutta township in the Ayeyarwady region of Myanmar

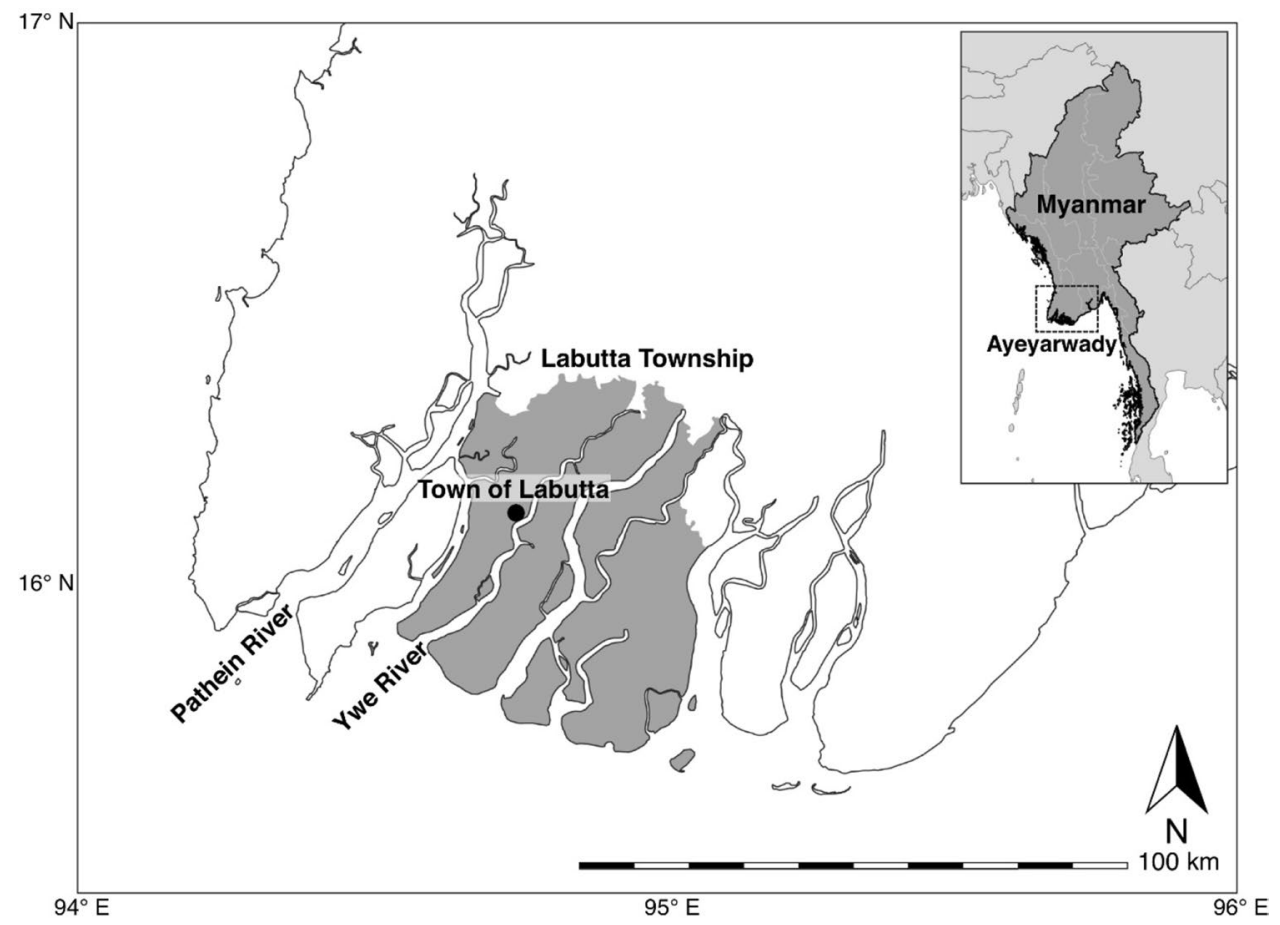

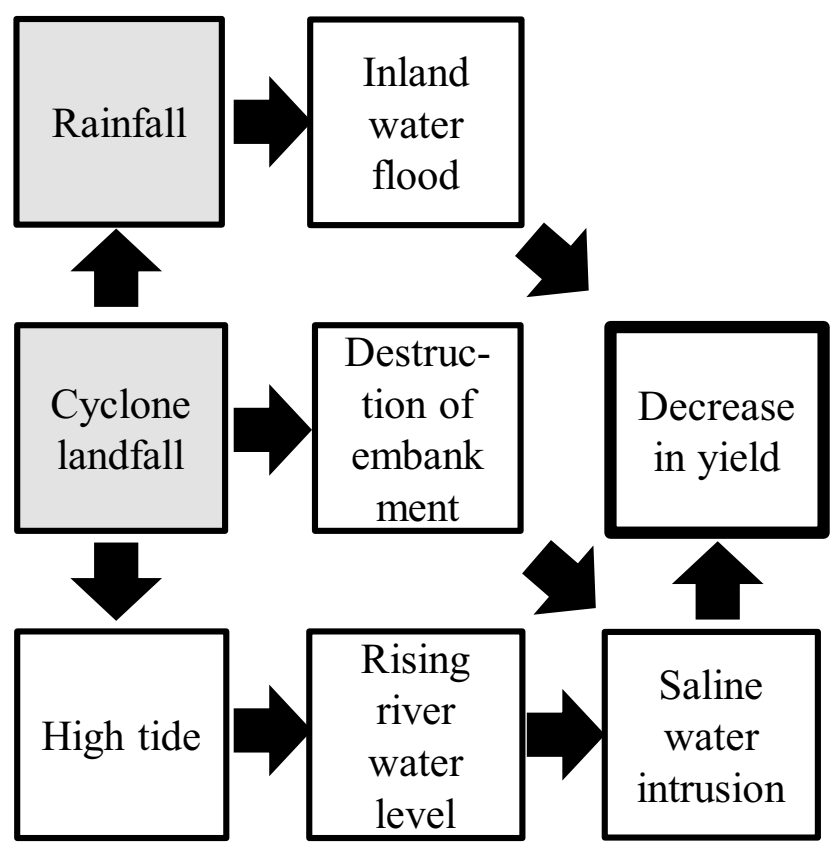

Fig. 2 Effects of weather shocks on production

cyclone landfall will engender heavy rainfall in this area. Not only cyclones, but also erratic rains will cause inland water flooding. The floods are presumed to decrease rice production. Therefore, frequencies of cyclone landfalls and erratic rains are important factors for designing the WII for this target area.

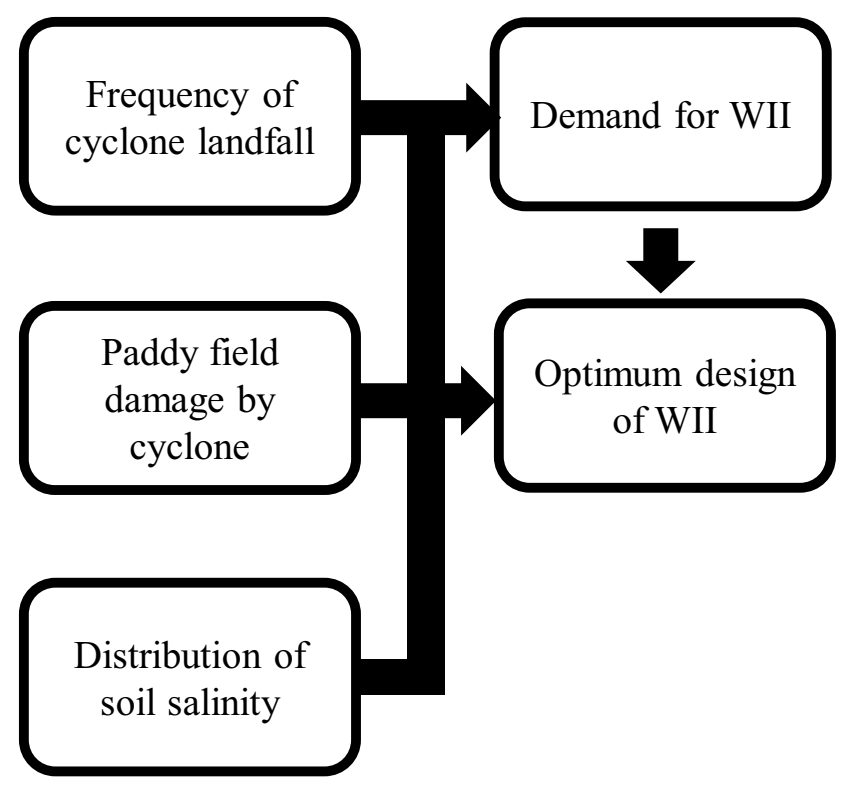

Fig. 3 Corresponding research themes

\section{Structure of the project}

Figure 3 presents topics of this research corresponding to the causality of weather shocks to agricultural production, as explained in the preceding section. First, remote sensing and statistical data were analyzed to elucidate risks for the target area. Secondly, demand of WII for each disaster type was investigated. Furthermore, a WII design is presented. The two components of this project are explained below. 


\section{Section 1: Remote sensing and statistical data analysis}

Coastal regions are exposed to severe occurrences such as high tides and saltwater intrusion. To identify risk aspects of the region and the probability of these events, the analyses were conducted using remote sensing and statistical data. Such identifications are expected to be helpful to decrease the basis risk in the target area.

As described, on 2 May 2008, the most powerful ever cyclone, Nargis, landed on the coastal region in Myanmar. Effects of extreme events such as the cyclone affect conditions of agricultural production and risk attitudes of farmers. First, the frequency of cyclone landfall in coastal region of Myanmar was analyzed using a 30-year historical tracing record (Hirano 2021). Actually, the probability of cyclone landing represents another important topic that must be addressed in future studies. Secondly, soil saline damage by the cyclone was investigated by comparison of soil electrical conductivity and the Normalized Difference Vegetation Index (NDVI) values (Omori et al 2020).

Zoning is an important means of elucidating differences of risk to disasters for designing crop insurance. Thirdly, decadal changes in single and double-cropping systems are investigated using the NDVI calculated from satellite data for better crop management (Sakai, 2021b). Furthermore, cultivable land in the dry season is classified using the satellite data.

\section{Section 2: Economic analysis}

This project was conducted to provide useful information related to the design of a WII in a coastal region. To approach the purpose, demand for WII for each disaster was analyzed. In addition, an optimum WII contract was investigated.

Basic information supporting the proposal for a new WII included price, coverage, and types of target disaster. Secondly, discrete choice experiments were used to investigate demand for WII related to the three attributes (Aizaki et al. 2021).

The basic question that must be answered for appropriate design of WII is how much farmers will pay as an insurance premium for sustainable management. Thirdly, an optimum contract for WII is investigated by estimating insurance compensation and cost according to a farmers' production level and risk attitude (Furuya et al. 2021).

\section{Uniqueness of the project}

Most indices of WIIs for commercial application are rainfall and temperature (Hazell et al. 2010). These indices are popular and easy to collect. However, soil and water salinity are the main problems in cyclone disaster-prone regions. Therefore, estimating these salinity levels is a key topic for the development of an agricultural WII in a coastal region. In this project, estimations of the salinity levels of soil and water were investigated using satellite data. These approaches are unique among research that has been conducted to evaluate WII.

To measure the demand for WII, some researchers conducted actual selling of insurance to farmers as a social experiment (Cai et al. 2009; Miura and Sakurai 2012; Cole et al. 2013). They were able to gather accurate data. However, the experimental related costs were usually high. Considering the risk of bearing the vast experimental related costs, discrete choice experiments approaches were selected in this project. Because this approach gathers data via questionnaire surveys, the implementation costs are low. Furthermore, this approach has been used to measure peoples' valuations of non-market goods and services in various fields such as environmental services and new products under development. Therefore, this approach demonstrated the usefulness of this type of experiment for WII development.

Deriving a demand function from a utility maximization model of a farm was also an individual characteristic of this project. Using the demand function, an optimum insurance money and premium were obtained under an assumed risk attitude and output price. These approaches will regulate the design of an agricultural WII system in coastal regions of South and Southeast Asian countries.

\section{Overview of results}

\section{Remote sensing and statistical data analysis}

\section{Frequency of cyclone landfall}

Hirano (2021) analyzed cyclone tracks in the Bay of Bengal using the 30-year dataset managed by the National Oceanic and Atmospheric Administration. The tracking data were split into two intervals of 1983-1997 and 1998-2012. The crossing of each $1^{\circ}$ grid cell was counted. Spatial analysis of the frequency of passing cyclones in a cell indicated that the regions through which cyclones pass frequently have moved during 30 years. Furthermore, results revealed that cells which were adjacent to the west part of the Ayeyarwady delta were changed to the high frequency of cyclone passing cells. It is expected that changes in the global climate circulation affect the cyclone landfall frequency.

\section{Quantification of damage from saltwater intrusion by the cyclone to paddy field}

Omori et al. (2020) analyzed effects of saltwater intrusion by cyclone Nargis on paddy fields in Labutta township. Changes in the NDVI during 2007-2008, i.e., the year 
preceding and the year of Nargis landfall, were, respectively, $-24.5 \%$ and $-17.9 \%$ at points $2.7 \mathrm{~km}$ and $23.3 \mathrm{~km}$ from the mouth of the Ywe River. Results revealed that the cyclone dramatically degraded vegetation in paddy fields. Moreover, the analysis of NDVI indicated that three years were necessary to recover the field. Cyclone Nargis landed during the pre-monsoon season. Therefore, the imposed saltwater was washed away by the rains. The actual yield of the rice did not decrease. However, if cyclones land during the post-monsoon season, then the paddy field soil is expected to accumulate salt.

\section{Monitoring of saltwater intrusion to rivers in the dry season}

Sakai et al. (2021a) developed a method of monitoring saltwater intrusion to rivers in the Ayeyarwady delta using highresolution satellite data. The saline level in the river water was estimated using the relation between the river water reflection and electrical conductance. Saltwater intrusion monitoring was done during November 2017-April 2018. Results indicate that the line of saltwater intrusion most moved to the inland in March. The distance from the river mouth to the saltwater intrusion line is expected to determine the cultivability of dry season rice. Monitoring the movement of the saltwater intrusion line is crucially important to identify the risks of rice cultivation during the dry season.

Regarding changes in the saltwater intrusion line, Sakai et al. (2021b) examined changes in rice planting areas during the dry season using the time series NDVI dataset in the Ayeyarwady delta region. Results indicate that the estimated area of double cropping of rice expanded during the last 30 years in the region. However, an analysis particularly addressing changes of NDVI showed that the vegetation was decreased in coastal areas including Labutta township.

\section{Economic analysis}

\section{Demand for WIIs}

Four main disasters affect coastal regions: cyclone landfall, flood, drought, and saltwater intrusion. Identifying which disaster commands the attention of farmers is necessary for designing the WII. Aizaki et al. (2021) conducted discrete choice experiments of WII on farmers in the ten village tracts in Labutta township. This experiment revealed the farmers' preference of premiums and coverage for WII for the disasters of four types. Results indicate that the farmers in Labutta township prefer WII programs that compensates damage of cyclone landfall, flood, and drought to a WII program that compensates farmers for damage by saltwater intrusion.

\section{Design of a WII}

The project results obtained from preference analysis revealed that a WII that compensates cyclone landfall and flood damage is demanded. Floods by inland water are caused by strong low-pressure systems including cyclones. Furuya et al. (2021) struggled to design a WII which compensated flood damage. That index for the central part of Labutta township was rainfall data. To obtain the optimum insurance payment and premium, a utility maximization problem for which the level of risk aversion is given was solved. The obtained insurance demand function revealed that if the rice cultivating farmers of Labutta township paid 41.5 US dollars per year, their farm income would be economically stable.

In addition to these analyses, evaluation to adaptation measure to flood damage and impact of introducing WII on rice productivity were investigated in this project.

\section{Conclusions}

To elucidate the probability of cyclone landfall, changes in tracks of cyclones in the Bay of Bengal were investigated. Moreover, the cyclone landfall effects on vegetation were analyzed. Spatial analyses of saltwater intrusion were also conducted because it is anticipated that these cyclone disasters increase the saline concentrations of water and soil. However, demand analysis of WIIs for each disaster type revealed that farmers in Labutta township prefer WIIs for cyclone landfall, flood, and drought to WII for saltwater intrusion. The reason for the low demand of WII for saltwater intrusion is that the farmers in Labutta township cultivate rice only during the rainy season. Salinity in soil has been washed away by continuous rains. It is anticipated that the WII of which the index is water saline level is applied in upstream regions such as the Myaungmya district. However, the demand of WIIs for cyclone landfall, flood, and drought was relatively high. The results indicate that strong winds and floods caused by the cyclone were a threat for the farmers. Drought is another obstacle for rice cultivation because these farmers cultivate rainfed rice in the township. The design of WII in this project emphasized only flood disasters. However, the calculation routine used to ascertain the optimum insurance compensation and premium is applicable to WIIs for drought and cyclone landfall, of which the respective indices are rainfall and distance from the center of cyclone. The introduction of WIIs will save farmers from disasters such as flood, drought, and saltwater intrusion. Furthermore, with the rapid effects of climate change on the horizon, such natural disasters are only bound to get worse. This finding further emphasizes the need for WIIs for farmers in coastal regions. 
Acknowledgements We extend our sincere appreciation to the former Rector Myo Kywe of the Yezin Agricultural University (YAU), ProRector Soe Soe Thein of the YAU, Head of the Department of Soil and Water Sciences Kyaw Ngwe of the YAU, and former Pro-Rector Khin Lay Swe of the YAU. They were supporting saltwater, soil, and farm surveys in Labutta township. This study was conducted with the benefit of the budget of "Climate Change Measures in Agricultural Systems project" of JIRCAS in collaboration with YAU, The University of Tokyo, and Hokkaido University.

Open Access This article is licensed under a Creative Commons Attribution 4.0 International License, which permits use, sharing, adaptation, distribution and reproduction in any medium or format, as long as you give appropriate credit to the original author(s) and the source, provide a link to the Creative Commons licence, and indicate if changes were made. The images or other third party material in this article are included in the article's Creative Commons licence, unless indicated otherwise in a credit line to the material. If material is not included in the article's Creative Commons licence and your intended use is not permitted by statutory regulation or exceeds the permitted use, you will need to obtain permission directly from the copyright holder. To view a copy of this licence, visit http://creativecommons.org/licenses/by/4.0/.

\section{References}

Aizaki H, Furuya J, Sakurai T, Mar SS (2021) Measuring farmers' preferences for weather index insurance in the Ayeyarwady Delta, Myanmar: a discrete choice experiment approach. Paddy Water Environ. https://doi.org/10.1007/s10333-020-00838-z

Barnett BJ, Mahul O (2007) Weather index insurance for agriculture and rural areas in lower-income countries. Amer J Agric Econ 89(5):1241-1247. https://doi.org/10.1111/j.1467-8276.2007. 01091.X

Cai H, Chen Y, Fang H, Zhou L (2009) Microinsurance, trust and economic development: evidence from a randomized natural field experiment, NBER working paper 15396

Chantarat S., Pannangpetch K, Puttanapong N, Rakwatin P, Tanompongphandh T (2012) Index-based risk financing and development of natural disaster insurance programs in developing Asian countries. In: Sawada Y, Oum S (eds) Economic and welfare impacts of disasters in East Asia and policy responses. ERIA Research Project Report 2011-8, ERIA, Jakarta, pp 95-151

Cole S, Giné X, Vickery J (2013) How does risk management influence production decisions? Evidence from a field experiment, Policy Research Working Paper 6546, The World Bank

Collier B, Skees J, Barnett B (2009) Weather index insurance and climate change: opportunities and challenges in lower income countries. Geneva Paper 34:401-424. https://doi.org/10.1057/ gpp.2009.11

Elabed G, Carter MR (2015) Compound-risk aversion, ambiguity and the willingness to pay for microinsurance. J Econ Behav Organ 118:150-166. https://doi.org/10.1016/j.jebo.2015.03.002

Elabed G, Bellemare MF, Carter MR, Guirkinger C (2013) Managing basis risk with multiscale index insurance. Agric Econ 44:419431. https://doi.org/10.1111/agec.12025
Furuya J, Mar SS, Hirano A, Sakurai T (2021) Optimum insurance contract of flood damage index insurance for rice farmers in Myanmar. Paddy Water Environ. https://doi.org/10.1007/ s10333-021-00859-2

General Insurance Association of Japan (2019) Number of payment and premium payment of various property insurance for windstorms and floods in 2018 fiscal year. (in Japanese) https://www.sonpo. or.jp/news/release/2019/1905_02.html

Hazell P, Anderson J, Balzer N, Clemmensen AH, Hess U, Rispoli F (2010) Potential for scale and sustainability in weather index insurance for agriculture and rural livelihoods, International Fund for Agricultural Development and World Food Programme, Rome. https://www.ifad.org/documents/38714170/40239486/The+poten tial+for+scale+and+sustainability+in+weather+index+insur ance+for+agriculture+and+rural+livelihoods.pdf/7a8247c7d7be-4a1b-9088-37edee6717ca

Hirano A (2021) Effects of climate change on spatiotemporal patterns of tropical cyclone tracks and their implications for coastal agriculture in Myanmar. Paddy Water Environ. https://doi.org/10. 1007/s10333-021-00842-x

SOMPO Holdings (2019) Adaptation to climate change. https://www. sompo-hd.com/en/csr/action/community/content4/. Accessed 1 March 2021

Miura K, Sakurai T (2012) Who purchases weather index insurance? Results from a field experiment in rural Zambia. J Rural Econ, 442-449 (in Japanese)

Omori K, Sakai T, Miyamoto J, Itou A, Oo AN, Hirano A (2020) Assessment of paddy fields' damage caused by Cyclone Nargis using MODIS time-series images (2004-2013). Paddy Water Environ. https://doi.org/10.1007/s10333-020-00829-0

Raju KV, Naik G, Ramseshan R, Pandey T, Joshi P, Anantha KH, Kesava Rao AVR, Moses Shyam D, Kumara Charyulu D (2016) Transforming weather index-based crop insurance in India: protecting small farmers from distress. Status and a Way Forward. Research Report IDC-8, International Crops Research Institute for the Semi-Arid Tropics, Telangana, India

Sakai T, Omori K, Oo AN, Zaw YN (2021a) Monitoring saline intrusion in the Ayeyarwady Delta, Myanmar, using data from the Sentinel-2 satellite mission. Paddy Water Environ. https://doi.org/10. 1007/s10333-020-00837-0

Sakai T et al (2021b) Decadal changes in the rice-cropping system in the Ayeyarwady Delta using a large archive of satellite imagery from 1981 to 2020. Paddy Water Environ. https://doi.org/10.1007/ s10333-021-00857-4

Viswanadhapalli Y, Srinivas CV, Basha G, Dasari HP, Langodan S, Ratnam MV, Hoteit I (2019) A diagnostic study of extreme precipitation over Kerala during August 2018. Atmos Sci Lett 20:e941. https://doi.org/10.1002/asl.941

Wei K, Ouyang C, Duan H, Li Y, Chen M, Ma J, An H, Zhou S (2020) reflections on the catastrophic 2020 Yangtze river basin flooding in southern China. The Innovation 1, 100038, August 28, 2020. https://doi.org/10.1016/j.xinn.2020.100038 